\title{
PENGARUH PERBEDAAN BAHAN PENGASAP TERHADAP UJI SENSORIK DAN KANDUNGAN GIZI KERANG DARAH (Anadara granosa) ASAP
}

\author{
The Effect of Smoke Material Diference to Sensory Testing and The Nutrient Content of Cockle shells (Anadara \\ granosa) Fumigation
}

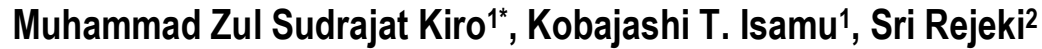 \\ 1Jurusan Teknologi Hasil Perikanan, Fakultas Perikanan dan IImu Kelautan Universitas Halu Oleo, Kendari, \\ Sulawesi Tenggara, Indonesia \\ 2Jurusan IImu dan Teknologi Pangan, Fakultas Pertanian Universitas Halu Oleo, Kendari, Sulawesi Tenggara, \\ Indonesia \\ *Email korespondensi: zulsudrajatkiro@gmail.com (Telp: +6282395124923) \\ Diterima: 15 Juli/ Disetujui 10 Desember 2019
}

Cara sitasi: Kiro MZS, Isamu KT, Rejeki S. 2020. Pengaruh perbedaan bahan pengasap terhadap uji sensorik dan kandungan gizi kerang darah (Anadara granosa) asap. Jurnal Fish Protech. 3(1):36-42.

\section{ABSTRACT}

This research is to determine the effect of fumigation with shell and coconut husks to sensory value and the nutritional value of cockle shells (Anadara granosa) fumigation. The tested samples have divided into three treatments and three repeated remixes with coconut fiber, coconut shell, and a mixture of coir and coconut shell for 40 minutes, therefore, this research was designed with a completely random design. The effect of the fumigation differentiation on sensory testing and cockle shell nutrient content (Anadara granosa) fumigation has done after the validator. The results showed that sensory value based on panelist data showed no apparent effect on aroma, a real effect on color, flavor, and texture. The result of a presentative nutritional test is likely to vary creatively during the total duration of each of the forty minutes, based on the best treatment of water content P1U1, P2U2, and P3U2 consecutive 34.34\%; $43.81 \%$; 43.69\%, ash content 3.40\%; 2.38\%;; 2.49\%, carbohydrate 5.97; 4.47\% ; 5.95\%, Protein $15.42 \% ; 18.54 \% ; 21.25 \%$, and fat 1.18\%; $1.12 \% ; 1.75 \%$.

Keywords: Anadara granosa, fumigation, sensory, nutrition.

\begin{abstract}
ABSTRAK
Penelitian ini bertujuan untuk menentukan pengaruh pengasapan dengan bahan pengasap tempurung dan sabut kelapa terhadap nilai sensorik dan nilai gizi kerang darah (Anadara granosa) asap. Sampel yang diuji dibagi menjadi tiga perlakuan dan tiga kali ulangan diantaranya pengasapan dengan sabut kelapa (P1), tempurung kelapa (P2) serta campuran sabut dan tempurung kelapa (P3) selama 40 menit oleh sebab itu penelitian ini di desain dengan rancangan acak lengkap. Pengaruh perbedaan bahan pengasap terhadap uji sensorik dan kandungan gizi kerang darah(Anadara granosa) asap dilakukan setelah pengasapan. Hasil penelitian menunjukan bahwa nilai sensorik berdasarkan data panelis menunjukan berpengaruh tidak nyata terhadap aroma, berpengaruh nyata terhadap warna, rasa dan tekstur. Nilai hasil uji gizi secara keseluruhan cenderung variatif selama total lama pengasapan empat puluh menit berdasarkan perlakuan terbaik yaitu kandungan air P1U1, P2U2, dan P3U2 berturut turut 34,34\%; 43,81\%; 43,69 \%, Kadar abu $3,40 \% ; 2,38 \% ; 2,49 \%$, Karbohidrat 5,$97 ; 4,47 \% ; 5,95 \%$, Protein $15,42 \% ; 18,54 \% ; 21,25 \%$, dan Lemak 1,18; 1,12\%; $1,75 \%$
\end{abstract}

Kata kunci: Anadara granosa, pengasapan, sensorik, gizi. 


\section{PENDAHULUAN}

Indonesia memiliki potensi sumber daya alam yang melimpah. Berbagai upaya dan cara dilakukan oleh masyarakat dan negara untuk memanfaatkannya. Sumber daya alam merupakan modal utama bagi suatu negara untuk kesejahteraan rakyat. Sulawesi Tenggara mempunyai potensi keanekaragaman hayati perairan yang cukup melimpah. Salah satu diantaranya adalah kerang darah (Anadara granosa) (Nurjanah, dkk, 2005).

Kerang darah merupakan salah satu jenis kerang dari kelas Bivalvia yang berpotensi dan memiliki nilai ekonomis untuk dikembangkan sebagai sumber protein dan mineral untuk memenuhi kebutuhan pangan masyarakat Indonesia. Kerang darah terdapat di pantai laut pada substrat lumpur berpasir dengan kedalaman $10 \mathrm{~m}$ sampai $30 \mathrm{~m}$ (Umbara dan Suseno 2006 dalam Sahara 2011). Produksi kerang darah di Indonesia pada tahun 2003 adalah 495,50 ton dan meningkat pada tahun 2004 menjadi 496.30 ton (DKP, 2004).

Menurut Moeljanto (1992) hasil perikanan merupakan komoditi yang cepat mengalami kemunduran mutu, atau mengalami pembusukan. Pengasapan salah satu jenis pengolahan yang dapat digunakan untuk menghambat kegiatan zat-zat mikroorganisme, salah satu produk olahan yang dilakukan adalah kerang dara asap.

Pengasapan merupakan salah satu cara menghambat laju proses pembusukan, yaitu untuk mengurangi kadar air sehingga bakteri pembusuk tidak akan cepat aktif lagi dan hasil produksi dapat disimpan lebih lama (Moeljanto, 1982). Pengasapan juga berfungsi untuk menambah citarasa dan warna pada makanan serta bertindak sebagai antibakteri dan antioksidan (Adawiyah, 2007). pengawetan tersebut dapat berpengaruh baik oleh mutu maupun daya awet produk yang diasap. Selain itu, cara pengawetan ini pun dapat mempengaruhi mutu dan daya awet mulai dari cara persiapan bahan, jenis asap yang digunakan, kelembaban, kecepatan pengasapan dan suhu pengasapan (Saleh dan Sari, 2007). Bahan pengasap yang digunakan dalam penelitian ini yaitu sabut kelapa dan tempurung kelapa. Menurut Afrianto dan Liviawati, (1989) zat-zat kimia yang dihasilkan dari pembakaran bahan bakar dalam proses pengasapan dapat memberikan warna kuning keemasan dan dapat memberikan daya tarik pada konsumen. Lebih lanjut dikatakan (Moeljanto, 1992) bahwa warna yang dikehendaki oleh konsumen sebagai warna ideal dari hasil proses pengasapan adalah warna kuning emas kecoklatan. Namun untuk kerang darah asap warna yg ideal coklat kemerahan hal ini disebabkan oleh warnah dasar daging kerang darah setelah perebusan berwarna agak merah kecoklatan.

\section{METODE PENELITIAN}

\section{Alat dan Bahan}

Bahan yang akan digunakan terdiri atas bahan utama dan bahan pendukung. Bahan utama adalah daging kerang darah segar. Bahan pendukung adalah tempurung kelapa, sabut kelapa, untuk bahan pengasap dan garam untuk cita rasa produk. Bahan kimia untuk analisis gizi adalah aquades, asam borat,reagen biuret, larutan standar protein, alkohol $80 \%$, petroleum eter, heksan, $\mathrm{NaOH}$ dan kertas saring.

Peralatan yang digunakan dalam penelitian ini ada 2 macam yaitu alat untuk pengolahan dan alat untuk analisis. Alat pengolahan meliputi: alat pengasapan, lemari drum asap sebagai alat pengasapan, baskom untuk menempati kerang darah segar, thermometer untuk mengetahui suhu pengasapan, stopwatch untuk mengetahui waktu pengasapan. Alat untuk analisis kandungan gizi meliputi: seperangkat alat ekstraksi soxlet, gelas piala, gelas ukur, batang pengaduk, pipet tetes, mikro pipet, corong, tabung reaksi, labu takar, erlenmeyer, desikator, sentrifus, timbangan analitik, gegep, cawan porselin, botol semprot dan spektofotometer UV-Vis. 


\section{Rancangan Penelitian}

Penelitian ini menggunakan Rancangan Acak Lengkap dianalisa dengan menggunakan metode ANOVA (Analysis of Variance). Penelitian ini terdapat 3 perlakuan yaitu kerang darah asap dengan menggunakan bahan pengasap sabut kelapa $3 \mathrm{~kg}$ (P1), kerang darah asap dengan menggunakan bahan pengasap tempurung kelapa $3 \mathrm{~kg}$ (P2) dan kerang darah asap dengan menggunakan bahan pengasap tempurung kelapa $1,5 \mathrm{~kg}$ dan sabut kelapa $1,5 \mathrm{~kg}(\mathrm{P} 3)$. Untuk masing-masing perlakuan dilakukan pengulangan sebanyak tiga kali dan dianalisis dengan 2 parameter uji yaitu uji sensorik meliputi aroma (aroma khas kerang darah asap), rasa, warna, tekstur, dan uji gizi meliputi kadar air, kadar abu, kadar lemak, protein dan karbohidrat

\section{Penyediaan Bahan Pengasap}

Kerang darah yang akan digunakan dalam penelitian ini diambil langsung dari pedagang kerang yang berada disekitaran jembatan Tripping By pass Kota Kendari. Setelah itu kerang dimasukan kedalam karung dan ditimbang dan dibawah kerumah produksi untuk dilakukan pencucian. Sedangkan bahan pengasapan tempurung dan sabut kelapa yang digunakan sebagai bahan pengasap diperoleh dari Kompleks pasar PKL Lawata Kota Kendari. Untuk pengambilan kerang dan bahan pengasapan tempurung dan sabut kelapa diangkut ketempat pengasapan menggunakan motor.

\section{Pengolahan kerang darah asap}

Proses pembuatan kerang darah asap dengan metode pengasapan tradisional dengan bahan baku pengasapan yang berbedah adalah kerang dicuci bersih untuk menghilangkan lumpur dan kotoran lainnya, kerang darah yang telah dicuci ditampung didalam keranjang dan. Kemudian kerang darah ditimbang sebanyak $8 \mathrm{~kg}$ dan dilakukan perebusan, kerang direbus selama 15 menit dan ditambahkan air sebanyak 4 liter dan dilarutkan garam sebanyak $80 \mathrm{gr}$. Kemudian setelah selesai pererebus lalu diadakan pemisahan daging kerang dan cangkangnya,kemudian daging kerang disimpan dalam wadah bersih. Setelah itu, kerang dikaitkan sampai 45 tusuk menggunakan tusukan sate pada umunya,dalam 1 tusukan berisi 8 daging kerang dan panjang tusukan $\pm 20 \mathrm{~cm}$, lalu dilakukan pengasapan selama 40 menit dengan suhu $900 \mathrm{C}$, menggunaka lemari pengasapan dengan perlakuan sabut kelapa (P1), sabut kelapa (P2), tempurung kelapa dan campuran sabut dan tempurung kelapa (P3), kemudian dilakukan pendinginan.

\section{Parameter Uji}

Parameter pengamatan pada penelitian ini yaitu analisis kandungan gizi meliputi kadar air, kadar abu,kadar lemak ,dan kadar protein pada produk olahan kerang darah asap.

Uji sensorik ini bermaksud untuk mengetahui tingkat penerimaan panelis terhadap kualitas sensorik pada produk kerang darah asap. Penilaian sensorik meliputi aroma (aroma khas kerang darah asap),rasa, warna, tekstur.

\section{Analisis Data}

Analisis sensorik dalam penelitian ini dianaliss menggunakanakan metode rancangan ANOVA( Analsis of Varians), untuk menilai penerimaan panelis terhadap nilai sensorik kerang darah asap yang meliputi warna,aroma (aroma khas kerang darah) rasa,tekstur dan rasa. analisis kandungan gizi dalam penelitian ini menggunakan data yang didapatkan. dihitung beratnya dengan taraf kepercayaan 95\% ( $\alpha=$ 0.05). 


\section{Uji sensori}

\section{HASIL DAN PEMBAHASAN}

Tabel 1. Rekapitulasi Hasil Analisis Sensori Dapat Dilihat Pada Tabel :

\begin{tabular}{lccc}
\hline Parameter & P1U1 & P2U2 & P3U2 \\
\hline Aroma \pm SD & $5,40 \pm 0,43$ & $5,83 \pm 0,32$ & $5,50 \pm 5,50$ \\
Warna \pm SD & $7,10 \pm 0,43$ & $5,10 \pm 0,62$ & $6,27 \pm 1,67$ \\
Rasa \pm SD & $4,27 \pm 0,41$ & $4,30 \pm 0,5$ & $4,27 \pm 0,30$ \\
Tekstur \pm SD & $5,10 \pm 0,43$ & $5,33 \pm 0,28$ & $4,70 \pm 0,36$ \\
\hline
\end{tabular}

Keterangan :

P1U3 : bahan pengasap sabut kelapa $3 \mathrm{~kg}$

P2U2 : bahan pengasap tempurung kelapa $3 \mathrm{~kg}$

P3U2 : bahan pengasap sabut $1,5 \mathrm{~kg}$ dan tempurung kelapa $1,5 \mathrm{~kg}$

Tabel 2. Hasil Analisis Kandungan Kimia

\begin{tabular}{lccc}
\hline Parameter & \multicolumn{3}{c}{ Perlakuan } \\
\cline { 2 - 4 } & P1U1 & P2U2 & P3U2 \\
\hline Kadar air (\%) & 34,34 & 43,81 & 43,69 \\
Kadar abu (\%) & 3,40 & 2,38 & 2,49 \\
Kadar protein(\%) & 15,42 & 18,54 & 21,25 \\
Kadar lemak (\%) & 1,18 & 1,12 & 1,75 \\
Kadarkarbohidrat (\%) & 5,97 & 4,47 & 5,95
\end{tabular}

Keterangan :

P1U3 : bahan pengasap sabut kelapa $3 \mathrm{~kg}$

P2U2 : bahan pengasap tempurung kelapa $3 \mathrm{~kg}$

P3U2 : bahan pengasap sabut 1,5 $\mathrm{kg}$ dan tempurung kelapa $1,5 \mathrm{~kg}$

\section{Uji Sensorik}

\section{Aroma}

Adanya perbedaan nilai sensori parameter aroma hal ini diduga disebabkan oleh sedikitnya asap yg terdapat pada bahan pengasapan tingginya nilai aroma pada tempurung kelapa diduga dipengaruhi banyaknya asap dan kandungan kimia tempurung kelapa pirolisis lignin yang mempengaruhi aroma pada pengasapan, seperti pernyataan Girard,(1992) yang menyatakab bahwa pembakaran pirolisis lignin menghasilkan aroma yang berperan pada pengasapan.lebih lanjut Moeljanto(1992) menjelaskan bahwa ketebalan asap atau banyaknya asap yang diserap oleh ikan akan menentukan aroma dan cita rasa ikan asap dan perlu disesuaikan dengan selera konsumen.Aroma yang dikeluarkan dari makanan merupakan daya tarik yang sangat kuat dan mampu merangsang indra penciuman sehingga membangkitkan selera. Menurut Isamu et al (2012) yang meneliti penilaian sensorik pada aroma ikan cakalang asap berbagai produsen yang terdapat di Kendari, yaitu bernilai berkisar $5,10 \pm 0,06$. Semakin tinggi konsentrasi asap yang diberikan maka aroma dan rasa asap pada ikan pun akan semakin meningkat dan ikan yang baru mengalami proses pengasapan memiliki aroma asap yang lembut sampai cukup tajam atau tajam, tidak tengik, tanpa bau busuk, tanpa bau asing, tanpa bau apek dan asam (Martinez et al., 2007).

\section{Warna}

Adanya Perbedaan nilai warna pada kerang darah asap diduga bahan pengasap yang berbeda, Semakin banyak asap yang dihasilkan maka warna yang dihasilkan berbeda. Menurut Afrianto dan Liviawati, (1989), zat-zat kimia yang dihasilkan dari pembakaran 
bahan bakar dalam proses pengasapan dapat memberikan warna kuning keemasan dan dapat memberikan daya tarik pada konsumen. Selain itu juga menurut Moeljanto, (1992) bahwawarna yang dikehendaki oleh konsumen sebagai warna ideal dari ikan hasil proses pengasapan adalah warna kuning emas kecoklatan. Namun untuk kerang darah asap warna yg ideal coklat kemerahan hal ini disebabkan oleh warnah dasar daging kerang darah setelah perebusan berwarna agak merah kecoklatan. Menurut Isamu et al (2012) yang meneliti penilaian sensorik pada warna ikan cakalang asap berbagai produsen yang terdapat di Kendari, yaitu nilai berkisar

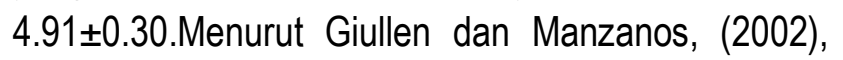
melaporkan bahwa asap dapat berperan sebagai pemberi warna pada tubuh ikan sehingga ikan yang diawetkan dengan proses pengasapan berwarna kuning keemasan dan dapat membangkitkan selera konsumen untuk menikmatinya. Semakin tinggi konsentrasi asap yang diberikan maka warna ikanpun akan semakin gelap atau kecokelatan

\section{Rasa}

Adanya perbedaan nilai rasa pada kerang asap hal ini menunjukan bahwa perlakuan yang diberikan mempengaruhi rasa kerang yang diasapi dan menunjukkan bahwa perlakuan yang diberikan berpengaruh nyata terhadap uji sensori rasa.Ini berarti kisaran kesukaan panelis terhadap rasa umami kerang darah asap berkisar antara sedikit terasa, terasa, kuat terasa. Hal ini dikarenakan oleh ketebalan asap atau banyaknya asap yang menempel pada daging kerang.Hal ini sesuai dengan pendapat llyas (1995), menyatakan bahwa proses penurunan mutu secara kimiawi yang mencolok kegiatannya disebabkan oleh oksidasi lemak yang akan mengakibatkan bau tengik dan perubahan rasa, selain itu rupa daging akan menjadi kusam. Rasa merupakan yang sangat penting dalam menentukan keputusan konsumen untuk menerima atau menolak suatu produk makanan. Rasa umami disebut sebagai rasa dasar kelima disamping rasa manis, asin, asam dan pahit. Agar suatu senyawa dapat dikenali rasanya, senyawa tersebut harus larut dalam air liur sehingga dapat mengadakan hubungan mikrovillus dan impuls yang terbentuk dikirim melalui pusat syaraf (Winarno, 2002).

\section{Tekstur}

Adanya perbedaan nilai teekstur hal ini diduga kosentarasi suhu dan ketebalan asap yg dihasilkan dari pembakaran sabut kelapa lebih tiggi dari tempurung kelapa, seperti yang dikatakan Isamu et al (2012), perbedaan nilai tekstur ikan asap diduga karena perbedaan kadar air, dimana semakin tinggi kadar air ikan asap, maka nilai teksturnya menjadi rendah, begitupun sebaliknya. .Menurut Isamu et al (2012) yang meneliti penilaian sensorik pada tekstur ikan cakalang asap berbagai produsen yang terdapat di Kendari, yaitu nilai berkisar 4,82 $\pm 0,28$.Simko, (2005), melaporkan bahwa selama pengasapan berlangsung terjadi fluktuasi suhu yang tinggi, sehingga menyebabkan kadar airnya berkurang dan menghasilkan tekstur menjadi lebih keras

\section{Kandungan Gizi Kerang Darah Asaap Kadar Air}

Berdasarkan hasil penelitian menunjukkan bahwa Jadi rendahnya kadar air diduga berhubungan dengan metode pengasapan yaitu menggunakan pengasapan tradisional dengan menggunakan bahan bakar yang berbeda yaitu sabut kelapa,tempurung kelapa dan proses pemanasan. Morintoh 20004 menyatakan bahwa semakin besar perbedaan antara suhu media pemanas dengan bahan yang dikeringkan, semakin besar pula kecepatan pindah panas ke dalam bahan pangan, sehingga penguapan air dari bahan akan lebih banyak dan cepat). Standar nilai kadar air ikan asap berdasarkan SNI adalah maksimal 60\%. Menurut Isamu et al. (2012) yang meneliti kandungan proksimat pada kadar air ikan cakalang asap berbagai produsen yang terdapat di Kendari,yaitu nilai berkisar $64,13 \pm 0,50$. Kadar air yang terkandung didalam ikan asap dapat mempengaruhi daya simpan ikan asap. Karena kadar air merupakan media mikroba untuk berkembang biak (Agus et al., 2014). 


\section{Kadar Abu}

Adanya perbedaan kandungan kadar abu sampel diduga disebabkan oleh lama waktu pengasapan dan suhu yang dihasilkan dari bahan pengasap. Menurut (Isamu et al 2012),disebabkan karena hilangnya kelembapan. Dan menurut Turan,(2008) pemasakan dan pengasapan pada beberapa biota laut akan mengalami kenaikan atau peningkatan kadar abu, misalnya pada mussel (Mytilus galloprovincialis) asap dari 0,95\% menjadi $6,02 \%$. Menurut Isamu et al (2012) yang meneliti kandungan proksimat pada kadar abu ikan cakalang asap berbagai produsen yang terdapat di Kendari, yaitu nilai berkisar1,56 $\pm 0,02$. Mardiana et al. (2014) bahwa persentase kadar abu berkorelasi positif terhadap lamanya pengsapan

\section{Protein}

Adanya perbedaan nilai protein diduga Karena perbedaan jenis bahan bakar yang digunakan Jenis bahan bakar sangat berpengaruh terhadap kadar protein kerang darah asap dan besarnya nilai kadar protein kerang asap sangat dipengaruhi oleh kondisi kerang yang digunakan.

Pengasapan kerang darah dengan bahan pengasap berbeda terjadi peningkatan kadar protein, hal ini diduga karena adanya tambahan garam dalam produk pengasapan dan rendahnya nilai kadar air. Hal ini didukung penelitian Tamrin,(2013) dimana peningkatan protein ikan sembilang asap terjadi karena penurunan kadar air.Hal ini sesuai dengan pernyataan Wibowo (1995) dengan susutnya kadar air maka protein dan lemak meningkat.Setiap perubahan nilai gizi yang terjadi akibat dehidrasi diduga berlangsung dibawah kondisi pengsapan .Menurut Isamu et al (2012) yang meneliti kandungan proksimat pada kadar protein ikan cakalang asap berbagai produsen yang terdapat di Kendari, yaitu nilai berkisar $31.13 \pm 0.44$. Hal tersebut didukung oleh pernyataan Swastawati et al. (2012) yang menyatakan bahwa kadar protein dapat menurun karena adanya proses pengolahan, dengan terjadinya denaturasi protein selama pemanasan

\section{Lemak}

Pada Tabel 2 menunjukan bahawa lemak kerang darah meningkat setelah pengasapan dan kadar lemak yang berbeda disetiap bahan pengasap yang berbeda. Peningkatan lemak pada kerang asap diduga disebabkan karena rendahnya kadar air pada kerang asap. Seperti pernyataan Robert dan Karmas ( 1989 ) kadar air bahan menurun menyebabakan kandungan padatan bahan seperti protein, lemak dan zat-zat vitamin akan meningkat Menurut Isamu et al (2012) yang meneliti kandungan proksimat pada kadar lemak ikan cakalang asap berbagai produsen yang terdapat di Kendari, yaitu nilai berkisar1.75 \pm 0.59 Pernyataan ini sesuai dengan Rampon (2002) menyatakan bahwa apabila kadar air ikan menurun maka kadar lemak akan mengalami peningkatan

\section{Karbohidrat}

Nilai pengasapan kerang darah mengalami peningkatan diduga proses penambahan garam dan pemanasan dari hasil pembakaran bahan pengasap yg terjadi pada kerang mengakibatkan peningkatan karbohidrat pada kerang

Pengasapan memberikan pengaruh pada komposisi unsur kimia yang terkandung pada kerang darah asap. Penelitian Isamu dkk. (2012), menyatakan bahwa terjadi peningkatan kadar protein, lemak dan abu sejalan dengan penurunan kadar air. Perubahan yang terjadi beragam pada tiap sampel. Hal ini diduga dipengaruhi oleh perbedaan bahan pengasap yang digunakan.

\section{KESIMPULAN}

Berdasarkan hasil penelitian dan pembahasan, maka dapat disimpulkan sebagai berikut:

1. Pada penilaian sensorik Kerang darah asap dengan bahan pengasap yang berbedadiperoleh perlakuan terbaik pada P2U2 (Tempurung kelapa) dan terjadiperbedan nyata terhadap attribute sensorik pada parameter warna, rasa dan tekstur.

2. Perbedaan pengolahan kerang darah asap dengan menggunakan bahan pengasap berbeda diperoleh nilai rata-rata gizi tertinggi pada P1 (bahan pengasap sabut kelapa) dan P3 (bahan pengasap campuran sabut dan tempurung kelapa) 


\section{DAFTAR PUSTAKA}

Adawiyah. R. (2007). Pengolahan dan Pengawetan Ikan. PT. Bumi Aksara. Jakarta.

Afrianto, E dan Liviawaty.1989. Pengawetan dan Pengolahan Ikan. Yogyakarta : Penerbit Kanisius.

Agus TSW, Swastawati F, Anggo AP. 2014. Kualitas Ikan Pari (Dasyatis sp) Asap Yang Diolah Dengan Ketinggian Tunggu Dan Suhu Yang Berbeda. Jurnal Pengolahan dan Bioteknologi Hasil Perikanan.3(1): 147-156.

[DKP] Dinas Kelautan dan Perikanan.2004 Keputusan Mentri Kelautan dan Perikanan Nomor KEP.10/MEN/2004 tentang pelabuhab perikanan.jakarta:DKP.

Moeljanto, 1992. Pengawetan dan Pengolahan Hasil Perikanan, Jakarta: Penebar Swadaya.

Nurjanah, Zulhamsyah, Kustiariyah. 2005. Kandungan mineral dan proksimat kerang darah (Anadara granosa) yang diambil dari kabupaten boalemo,Gorontalo. Buletin Teknologi Hasil Perikanan 8(2): 15-24

Girard, J. P. 1992. Smoking in Technology of Meat and Meat Product. Ellis Horwood. New York.

Giullen MD, Manzanos MJ. 2002. Study of the volatile composition of an aqueous oak smoke preparation. Food Chemistry. 79:283-292
Isamu, K.T., H. Purnomo, dan S.S.Yuwono. 2012. Karateristik Fisik, Kimia, dan Organoleptik Ikan Cakalang (katsuwonus pelamis) Asap di kendari. Jurnal Teknologi Pertanian, 13:105-110.

Martinez O, Salmeron J, Guillen MD, Casas C. 2007. Sensorial and physicochemical caharacteristics of salmon (Salmo salar) treated by different smoking process during storage. Food Science and Technology International. 13(6): 477-484

Suprapti,N.H.2008. Kandungan chorimum pada perairan,sedimendan kerang darah anadara granosa L.diwilayah pantai sekitar muara sayung,desa morosari kabupaten demak, jawa tengah. Jurusan biologi FMIPA Universitas Diponegoro.

Tamrin. 2013. Teknik Pengering. Buku Ajar. Universitas Lampung: Lampung. $247 \mathrm{hlm}$.

Turan H, Guls A, Sonmez M, Celik M, Yalcin M, Yalcin K. 2008. The effect of hot smoking on the chemical composition an $s$ helf life of mediteranian mussel (Mytilus galloprovincialis $L, 1819)$ under chilled storage. Journal of Food Processing and Preservation 32: 912-922.

Winarno FG. 2002. Kimia Pangan dan Gizi. Gramedia Pustaka Utama. Jakarta 